Meta

Journal des traducteurs

Translators' Journal

\title{
Equivocal Economic Terms or Terminology Revisited
}

\section{Catherine Resche}

Volume 45, numéro 1, avril 2000

La traduction littéraire au Canada

Literary Translation in Canada

URI : https://id.erudit.org/iderudit/003940ar

DOI : https://doi.org/10.7202/003940ar

Aller au sommaire du numéro

Éditeur(s)

Les Presses de l'Université de Montréal

ISSN

0026-0452 (imprimé)

1492-1421 (numérique)

Découvrir la revue

Citer cet article

Resche, C. (2000). Equivocal Economic Terms or Terminology Revisited. Meta, 45(1), 158-173. https://doi.org/10.7202/003940ar

\section{Résumé de l'article}

Cette étude vise à mettre en évidence l'existence d'un type de terminologie floue dans des sciences non dures comme les sciences économiques. Dans un premier temps, l'accent est mis sur des termes particulièrement difficiles à cerner puisque le signifiéévolue au gré des circonstances alors que le signifiant reste inchangé ou qu'il y a inadéquation entre signifié et signifiant. Ensuite, divers procédés linguistiques tels que la néologie, l'euphémisme, la métaphore, l'oxymoron, la réduction sont identifiés comme autant d'entraves possibles à la clarté requise en terminologie. Enfin, l'analyse se concentre sur les causes permettant d'expliquer l'existence de ces termes élastiques qui doivent néanmoins être pris en compte pour aider étudiants étrangers et traducteurs à déjouer les pièges tendus et à mieux maîtriser la langue spécialisée.
Ce document est protégé par la loi sur le droit d'auteur. L'utilisation des services d’Érudit (y compris la reproduction) est assujettie à sa politique d'utilisation que vous pouvez consulter en ligne.

https://apropos.erudit.org/fr/usagers/politique-dutilisation/ 
N.D.L.R. Un incident technique malencontreux a amputé ce texte de Catherine Resche dans Meta 44-4 aux p. 617 à 632. Nous nous en excusons auprès des lecteurs et bien sûr de l'auteur. Nous reproduisons le texte dans son intégralité ci-dessous.

\title{
Equivocal Economic Terms or Terminology Revisited
}

RÉSUMÉ

Cette étude vise à mettre en évidence l'existence d'un type de terminologie floue dans des sciences non dures comme les sciences économiques. Dans un premier temps, l'accent est mis sur des termes particulièrement difficiles à cerner puisque le signifié évolue au gré des circonstances alors que le signifiant reste inchangé ou qu'il y a inadéquation entre signifié et signifiant. Ensuite, divers procédés linguistiques tels que la néologie, l'euphémisme, la métaphore, l'oxymoron, la réduction sont identifiés comme autant d'entraves possibles à la clarté requise en terminologie. Enfin, l'analyse se concentre sur les causes permettant d'expliquer l'existence de ces termes élastiques qui doivent néanmoins être pris en compte pour aider étudiants étrangers et traducteurs à déjouer les pièges tendus et à mieux maîtriser la langue spécialisée.

\begin{abstract}
This paper aims at focusing on a category of oddly flexible terms found in social sciences such as economics that seem to call into question the fundamental principles of welldefined terminology. The first part is devoted to particularly deceptive terms either because their meaning varies over time, although they appear unchanged, or because the relation between the signifiant and the signifié is stretched beyond recognition. The second part examines various linguistic or rhetorical techniques such as neologisms, euphemisms, metaphors, oxymorons and reductions that lead to the blurring of notions and meanings. Finally, the causes that allow such loose terminology to arise are investigated. The need to record and identify the evolution of these fuzzy terms is all the more pressing as foreign students of English for specific purposes, as well as translators, have to be guided around the pitfalls and be given a chance to improve their mastery of all the aspects of a given terminology.
\end{abstract}

\section{MOTS-CLÉS/KEYWORDS}

Terminology, Economics, deceptive terms, rhetorical techniques, LSP

\section{Introduction}

Terms, by definition, are associated with precise notions, concepts or objects (Dubuc 1978) and they are most often univocal, at least in the specialised fields or sub-fields in which they are used (Bally 1935: 56): "Donner aux objets des noms exacts et non équivoques, c'est le propre de la science, de la technique, non du langage courant."

Ideally, terms correspond to a clearly identified reality and each word in their definition has been carefully checked to give the most accurate information as to their semantic content. Technical terms should be the best possible marriage between meaning and form. The principal aim of terminology is to clarify notions in order to avoid misunderstandings or ambiguity (Bouveret 1998; Guilbert 1965: 337): "Le trait 
spécifique de la terminologie technique est la recherche de la monosémie par opposition à la polysémie généralisée des termes du lexique général de la langue." To this end, new terms may have to be coined in order to fulfil the needs of new technologies, methods, processes - this accounts for neologisms - and to be coherent with the rest of the terminology of a given field. Besides, existing terms need to be specified and their use standardised to guarantee that people 'speak the same language' and resort to the same terms when referring to the same reality.

Clearly, for exact sciences and techniques, terminology is vital to identify parts of a machine, tools, or to refer to aspects of a theory, but for what we shall call 'softer' sciences in this paper - of which economics is a perfect example — the approach to terminology is somewhat more intricate and needs to be qualified. We do not mean to question the existence of specific economic terms that are indispensable when describing financial instruments or referring to established theories, but we would like to suggest a parallel terminology which is, so to speak, more flexible and which calls to mind such notions as vagueness and confusion. Here lies the paradox suggested in the title of this paper.

Specifically, our purpose here is to analyse the different aspects of the misleading terms we have encountered and recorded in our corpus, with a view to sensitising teachers and students of English for specific purposes, as well as translators and terminologists, to the risks inherent to a number of terms that may not be as clearly defined as they seem to be at first glance. We would also like to draw their attention to the potential elasticity of some terms, by which we mean that the relationship between meaning and form is likely to be stretched.

We must bear in mind the pervasive presence of man in all economic matters; the psychological dimension cannot be ignored. Invariably, economic developments have an impact on people and, therefore, the underlying terminology is impregnated with terms that offer a scope for fluctuating interpretations and nuances. It follows that the terms can hardly be used in a neutral way. While well-established, precise terms are helpful tools, the looser terminology we are alluding to can conceal dangerous traps. For this very reason, it has to be investigated, not only in order to give a more complete understanding of the workings of the language, but also to provide a guide towards greater authenticity: as they are actual components of a given terminology, the looser terms have to become familiar enough to be re-used spontaneously in appropriate situations.

We have mainly focused on such areas as investments and prices, economic analysis, international trade and corporate management. Our corpus was compiled with a view to covering both scientific literature - research in economics as well as course books (Barro and Grilli 1994, Dornbusch and Fischer 1988, Samuelson 1998) - and the press (The Economist). What we had in mind when building the corpus was to avoid the risk of restricting our research to one type of source, which might have led us to draw biased conclusions. It was impossible at first to guess where the 'soft' terminology would be most frequently used or even whether it would have its place in all three types of texts. Actually, we assumed that research articles, meant to be read by specialists, would abound with hyper-specialised terms, understandable only to a limited circle of experts. However, the opposite hypothesis is also receivable: the readers should be able to fill in information gaps without any problem, so these articles may well contain a number of vague terms. In the case of course books, the 
two options were also valid: either they would make a point of using the proper terms to set the example, or they might prefer a softened terminology that would be more easily read by students. As for the press, which addresses a more varied readership, it could be expected to use the received terms in order to live up to its status the specialised, economic press - or, in an effort to popularise economic concepts or simply to bring the financial news to the readers, it could understandably choose to avoid the technical terms and opt for a softer version. Whatever the motivations, a simplified and reduced use of terminology unavoidably contains risks of misuse or even abuse, instances of which are at the heart of our present preoccupations.

To simplify the structure of this study, we have chosen to organise our approach along lines that reflect the linguistic processes characteristic of the terms under scrutiny, rather than gather those terms according to the areas of economics to which they pertain (See Appendix 1 for the complete list.) We first deal with misnomers. Then we turn to various linguistic processes that appear to have given rise to a host of fluctuating terms. Finally, we widen the scope of our investigations to include periphrastic phenomena and we analyse the reasons for this elastic economic terminology, so to speak - 'elastic' being intended to convey the idea of bent, distorted, stretched and fluctuating meanings.

\section{MISNOMERS}

According to the Collins-Cobuild English Language Dictionary, "a misnomer is a word used to refer to something but which describes it wrongly or inaccurately." Misnomers obviously pose problems to the layman but even the reader who is more familiar with a given field may have trouble with terms that hide a new or unexpected meaning under a seemingly familiar surface.

Though we are all aware of the arbitrary nature of the linguistic sign (Saussure 1969: 101), we still expect specialised terms to denote specific concepts more rigorously and to be anything but misleading. Yet, in the field of economics, a number of misnomers have focused our attention. They can be divided into two categories which we shall examine in turn. On the one hand, we can find terms that do not automatically cause suspicion because they are apparently well-known and frequently used, though their meanings fluctuate over time, according to changing concepts and theories. On the other hand, we can notice terms that are characterised by an unsettling dichotomy between meaning and form, between what Saussure called signifié and signifiant in French.

\subsection{Terms and diachrony}

Terminologists who advocate tracking the evolution of terms over time are involved in "terminochrony" (Moller 1998). Time can indeed affect terms and notions in different ways, changing either meaning or form or both and to various degrees. In this section, we shall limit our observations to only one aspect, namely the change that affects meaning and thus use, but not form - we shall quote examples of successive generations of terms later, when dealing with neologisms. Terms that look unchanged but have fluctuating meanings are all the trickier as people may not take heed of them and risk being fooled by their familiar appearance. 
To illustrate this point, let us consider the area of macroeconomics devoted to the analysis of the business cycle, a topic which is or seems to be familiar to many readers, even the general public. To start with, the very term business cycle is in itself misleading as Barro and Grilli (1994: 30) point out:

It suggests a more regular pattern of ups and downs in economic activity than actually appears in the data. But the term is too entrenched in the economic literature to avoid entirely.

Samuelson's explanation (1998: 433) throws light on the elastic life span of a cycle and draws attention to the recent evolution of the notion:

A business cycle is a swing in total output, income and employment usually lasting for a period of 2 to 10 years, marked by widespread expansion or contraction in most sectors of the economy... In modern economics, business cycles are said to occur when actual GDP rises relative to potential GDP (expansion) or falls relative to potential GDP (contraction or recession).

We should not overlook the fact that theories and analyses are constantly challenged by economic developments and changing times. New findings call former established notions into question, truths are relative, concepts evolve and, accordingly, in their wake, so does the semantic content of terms. This is evidenced by the current debate about whether the business cycle is still a relevant concept or whether it is "dead", so that we might well soon wonder if the term should not be considered as referring to a notion which has ceased to exist. Contained in the definition are three terms belonging to the familiar terminology of the business cycle - expansion, contraction and recession - that also call for a few remarks. If Samuelson seems to put contraction and recession at the same level, as do Barro and Grilli (1994: 5), the latter go further and also draw a parallel between boom and expansion on the upside, as appears from the example below:

When real GNP falls toward a low point or trough, the economy is in a recession or an economic contraction. These are periods characterized by negative rates of growth. Conversely, when real GNP expands toward a high point or peak, the economy is in a boom or an economic expansion. These are periods characterized by high rates of growth.

However, neither context gives any clue as to when to call a rise a boom or whether there are slight differences between a recession and a contraction: can any contraction, for example, be called a recession? Again, Samuelson underlines the impact of time on definitions by insisting that "the precise definition of a recession today is a period in which real GNP declines for at least two consecutive calendar quarters" and he adds that, though a recession is "a milder form of business downturn" than a depression, it has many of the features of a depression, only to a lesser extent. ${ }^{2}$ Let it be added that, while in the 19th century, downturns were traditionally called... depressions, the latter term seems to have had a bad reputation in the 1930s, so that "recession" was coined to replace it. We realise that we are not really dealing with changing definitions, but with fluctuating, often subjective assessments of situations, which require constant updating of the underlying meaning. We shall later return to the link between the time factor and trends or fashions. At this point, we just intend to insist on the need to put the terms back in their context and take the diachronic factor into consideration if one wants the fog to start clearing. 


\subsection{Terms as disguise}

The terms that we have in mind, here, are terms that announce one thing on the surface while their profound meaning will prove surprisingly different. Seemingly innocent terms like curve, used in graphic analysis, will illustrate our point. In addition to describing either dome-shaped or U-shaped lines, the term can be used in quite a disconcerting way, as pointed out by Deconinck-Brossard and Offerle (1996: 23):

A line graph, misleadingly called a curve, even though it may be straight and jagged, joins the points that have been plotted from their coordinates along the $\mathrm{x}$ - and $\mathrm{y}$-axes.

For such uses, no logical criterion can help. References to everyday experience of curves as anything but straight or jagged lines - the curves of a woman's body, the curves of a road - can only lead to more confusion. This is especially true for compound words, as illustrated by the expression terms of trade. Foreign students in international trade must be taught that the term does not refer to the specific terminology of international trade but to "the ratio of export prices to import prices"3 (Samuelson 1998: 692).

Yet another sub-field of economics, i.e. investments, offers us a telling example of the traps to be avoided with the term hedge fund. If one considers that the compound term is equal to the sum of its parts, one is bound to misunderstand the notion. It is true that "to hedge," whether in linguistics or in economics, does mean to be cautious in one's statements or investments, to protect oneself against some sort of risk - of being criticised, of losing money. However, this term, which dates back to the early 1950s, has evolved. While it initially described collective investment vehicles that combined two investment techniques - short sales and leverage - in a way that reduced risk, it now very often refers to a highly speculative and risky form of investment, which might deceive uninformed would-be investors who naively trust the term to give an accurate description of the instrument it denotes.

As a final example, we shall quote the terms euromarket, eurocurrency and eurobond, to underline that, in spite of the 'euro' prefix, neither of them ever referred to European currencies; nor do they now refer to the euro, the European single currency. Instead, all currencies held outside their countries of origin — in banks round the world - are called eurocurrencies, another term for stateless money. The "euro" part of these terms results from the fact that, originally, the deposits were made with European banks, but the extension to the rest of the world for such deposits has not been accompanied by a change in the terms, hence the likely confusion. Likewise a eurobond should not be mistaken for a bond denominated in euros.

Clearly, it seems wiser for teachers, translators or terminologists, to record rather than ignore the looser terms and to identify the linguistic processes that contribute to the emergence of such terms. By lifting the veil of haze that can only impair understanding, they will perform a useful service for the community of potential users.

\section{THE LINGUISTIC PROCESSES FEEDING THE CONFUSION}

"Terminology revisited" is meant to suggest two different ideas. The first is that terminology should not only record terms for established notions but it should also 
explore the quirks in the conceptual denomination process. The second meaning of "terminology revisited" refers to the various ways in which terms can be stretched, tinted, twisted, consciously or not, to such an extent that people tend to lose their marks. Thus, terms lose their principal use, that of being concept markers for them. Let us now deal with some of these devices.

\subsection{Oxymorons}

A closer look at the terminology of graphical analysis or trade reveals unusual associations of terms which contradict the ISO recommendation (ISO R 704), according to which, as Sager (1981: 212) reminds us,

a terminological system should ideally be constructed in such a way that it is transparent in its reflection of the knowledge structure, so that inferences about the reference of an unknown term are possible on the basis of its form alone.

The terms flat curve, zero slope or voluntary export restraints, to name but a few oxymorons - or "couplings of words that are strictly contradictory" (Matthews 1997: 261) — can only be disturbing. How can a curve be flat? Does the idea of zero not automatically exclude that of a slope? How can one willingly limit one's freedom to export? Still, Dornbusch and Fisher (1988: 119-120) comment on the IS curve (representing investment spending) as follows:

If a given change in the interest rate produces a large change in income, the IS curve is very flat... This is the case if investment is very sensitive to the interest rate... As we see from the lower figure, the larger the multiplier, the flatter the IS curve.

The second oxymoron, i.e. zero slope, cannot be understood unless the meaning of slope in graphical analysis has been made clear:

The slope of a line represents a change in one variable that occurs when another variable changes. More precisely, it is the change in the variable $Y$ on the vertical axis per unit change in the variable $X$ on the horizontal axis. (Samuelson 1998: 19)

Only after reading the definition can one understand what is referred to by "zero slope": in the case of a dome-shaped curve, we are told that the slope is always positive in the rising region, negative in the falling region and exactly zero at the peak or maximum of the curve (Samuelson 1998: 22):

A zero slope signifies that a tiny movement in the $X$ variable around the maximum has no effect on the value of the $Y$ variable.

As for the third term, encountered in the context of international trade, its oddity lies in the adjective "voluntary." Returned to its original context, the term refers to a situation where, under the threat of anti-dumping duties, foreign firms have no choice but to agree to "voluntary export restraints" (at presumably higher prices). In other words, these voluntary export restraints are coercive, albeit indirectly. They should actually be called "compulsory import restraints." As The Economist (February 20th 1999, "Treacherous Trade") puts it, after giving the example of Japan which has been under pressure from the United States to accept voluntary targets for expanding its imports, "all this is about as voluntary as handing your wallet to a mugger." 
If the first two examples from the field of graphs can be viewed as unsettling, it is essentially due to their awkward denominations; once the definitions have been verified, the terms can be used without any bias. It is not so for the third oxymoron and we shall discuss what may have motivated the twisted meaning later. For the moment, we would like to pass on to new or recent terms that can be disconcerting in other respects, even though they do not represent such a challenge for the reader's logical mind.

\subsection{Neologisms}

Corporate management is an area of economics which abounds with newly-minted words to translate the theories of the management gurus who keep prompting reforms in the organisation of firms and have even brought about a revolution by questioning existing hierarchies. Once again, time remains an important parameter. ${ }^{1}$ No doubt, there was a need for new terms to describe some of the new practices. Yet, quite interestingly, other terms were coined just to replace existing ones, and thus the risk of confusion increased. Many of these terms were motivated by the desire to keep up with the evolution of tastes and to meet specific requirements, which we will discuss later, but we can already stress that it was no coincidence that firms were advised to slim and downsize at a time when the world of fashion was imposing slender models, when slim meant both "beautiful" and "healthy." A great number of neologisms then flourished to paint a rosy picture of a situation that was not so pleasant for the victims of delayering, both the middle managers who lost their jobs and those in the lower layer, who, despite the flattering term empowerment, were not really given more power, but surely more work to do - their own and that of the unfortunate, displaced, middle-managers.

Very soon, a second-generation of neologisms was born and re-engineering replaced rationalising to describe the restructuring of firms. The younger generation of terms is even more destabilising than the former one: downsizing has now been changed into rightsizing as the "down" part of the word was indeed potentially depressing. Assuredly the new term refers to the new size that can be hoped to be just right for the firm, but one may wonder if it is felt to be right by those who lose their jobs in the process. Likewise, outplacement has given way to inplacement, a misnomer again as the employees concerned do not remain in the firm. Characteristically, the outplacement offices have been christened career centres, specialised in giving the employees who have lost their jobs the information they need to move to new jobs. Last but not least, it is important to note that plateauing - surely better than stagnating - enables people to move sideways in the company, but not upward. All the terms in this section illustrate once more the impact of chronological development on a given terminology and lie at the crossroads between neologisms and euphemisms, which are worth giving extra attention.

\subsection{Euphemisms}

Under this heading, we shall examine turns of phrases that require reading between the lines, interpreting the gap between surface meaning and profound meaning. A euphemism is a mild or vague expression substituted for one thought to be crude or 
unpleasant. In this respect, one of our former examples, "delayering," is a soft substitute for "laying off." So is "externalised." The unpleasant fact of having to part with workers or staff members can simply be obscured, obliterated thanks to euphemisms. Corporate boards have proved very imaginative in avoiding such painful terms as "axing," so that a wide range of new terms have been made ample use of. Besides the unfortunate middle manager who is given the pink slip, luckier ones will be kicked upstairs, i.e. given a "promotion." For someone in a relatively important position, whom it is always more difficult to lay off, the human-resources director can always suggest that he take gardening leave, by which he means that the person will stay away from the office. Officially, the company will declare that the same person intends to spend more time with his family, while, on his own $\mathrm{CV}$, the victim will mention this jobless period as a period when he put his career on hold or was between jobs. When jobs are cut, people go into repositioning or they develop their careers elsewhere (The Economist, April 10 1999, "So Many Ways of Saying Good-Bye”).

The same art of understating facts is cultivated in other branches of economics. Assessments of the state of the economy and forecasts of future likely developments may read as follows (Prudential Securities Research Weekly, February 22 1993: 4): "supply is catching up with demand," when, were it to be simply stated, they mean "demand is slowing." Course books use the term imperfectly anticipated inflation as opposed to "fully anticipated inflation" (Dornbusch and Fisher 1988: 563):

The notion that the costs of fully anticipated inflation are small does not square well with the strong aversion to inflation reflected in policy making and politics. The most important reason for that aversion is probably that inflations in the United States have not been steady, and that the inflationary experience of the United States is one of imperfectly anticipated inflation.

The words "unexpected" or "unanticipated" would indeed tend to question the ability of analysts and specialists to evaluate the situation accurately.

Quite ironically, understatements can be found in the field of accounting, where one should give a fair view of the situation. Precisely, creative accounting is a roundabout way of meaning that "figures have been twisted beyond the bounds of decency to present the picture the company wants" (Brett 1992: 36). The reader will, no doubt, appreciate the euphemistic dimension of this very definition. "Creative accounting" was also used recently to refer to the one-off measures - like a special European tax - taken by various European countries to manage to meet the Maastricht criteria in time to be entitled to full membership of the euro club.

The euphemisms in our examples are mostly used to soften unpleasant news or to avoid terms with a negative ring that would be deemed too crude. They can also be attempts at fooling people, at painting a decent picture of a not-so-decent reality. In many cases, they lead their authors to resort to longer phrases in order to go round the "raw" terms. Another means of avoiding being too direct is, on the contrary, to reduce terms to a minimum.

\subsection{Reductions}

"Reduction to the extreme" would be a more accurate description as the reduced terms are here limited to their initial letters. The reason for this is not laziness, but rather a sort of superstition. The taboo terms inspire such fears, they seem to have 
such a dreadful potential impact that they are simply boycotted in some circumstances for fear they should bring a curse on future economic development. It is a form of self-imposed censorship, a tacit agreement to ban those "dirty words" from the language.

The first such "four-letter word" has four letters precisely: it is the $S$-word (which stands for S-E-L-L, provided the reader is familiar with the trick). It can be encountered in the context of financial comments on company shares read by shareholders for advice. The Economist (April 17th 1999) provides valuable statistical information on the matter, revealing that, today's share recommendations by analysts are unevenly divided between "sells" (1\%) and "buys" (68\%), while the ratio of buys to sells was roughly one to one in the early 1980s:

The reason analysts have stopped uttering the S-word is that it no longer pays them to do so, even when they should; indeed, it might get them fired.

In addition to hurting the feelings of company managers, an official "sell" recommendation also risks triggering a wave of panic among the public of shareholders rushing to follow the advice, thus causing prices to drop further. Consequently, it is vital for investors to be aware of the new trend and to learn to read between the lines when an analyst lowers his recommendation from "strong buy" to "buy" and then again to "hold" or "neutral."

Likewise, a series of initials can be found in the economic terminology, such as the $B$-word (for bubble), I-word (for inflation), or $R$-word (for recession). An interesting example is that of the P-word, which is used in specific contexts where privatisation is considered a thorny issue. Such is the case with an article about New York's infrastructure where "The P-word" serves as sub-head (The Economist, August 29th 1998) and the first sentence is quite telling:

One of the ideological quirks of the modern world is that privatisation may now be less politically correct in New York than in either Moscow or Beijing.

Some of these words, such as the D-word, can be very puzzling, as " $\mathrm{D}$ " could logically be interpreted as "deregulation," "depression," “deflation,"4 or even "danger." Only the context can help to find the answer (The Economist, February 20th 1999):

Talk of deflation is certainly at its highest level since the 1930s. The number of newspaper articles mentioning the $\mathrm{D}$-word is running at more than 20 times the rate of a decade ago.

The article also provides a graph of the D-ratio to illustrate the point. It is worth noting, however, that a different context may change the underlying meaning of the $\mathrm{D}$-word altogether. In the following example, associated with the problem of pension plans, the letter " $\mathrm{D}$ ” no longer stands for deflation, but for derivatives (The Economist, July 31st 1999):

Once members of Philips' new money-purchase pension plan turn 50, their trustees switch their funds gradually into a combination of cash and derivatives. ... But many are intimidated by derivatives. "You need an intelligent trustee to agree to the Dword"...

In some cases, the reduced term does not even include "-word," as in "Return of the Dread-I," the title of an article about inflation (The Economist, May 22nd 1999). 
Strange as they may seem, these reductions to the initial letters of the words are terms all the same, and it is all the more important to record them as they have to become familiar to anyone reading about economic matters in English. They are part of the terminology that anyone wishing to speak and write authentically should master. They also reinforce the idea that contexts are indispensable sources of information in terminology.

\subsection{Metaphors}

We have already dealt with the heuristic and other functions of metaphors in economics in other circumstances (Resche 1998: 70-71). If we have chosen to mention a certain type of metaphor within the framework of this study, it is only in so far as they have a blurring effect on terminology. Let us briefly consider the problem. When a falling market is personified and described as having human reactions, the inevitable impression for any reader will be that the message is clear, simple to understand. However, a market described as shuddering, swooning, or haemorrhaging, will only fool the public into considering the information as crystal clear; actually, no real indication as to the percentage of the fall in prices, the extent of the problem or the length of the crisis is given here. Other metaphors to describe rises, borrowed from other fields, such as ballooning, soaring or burgeoning, are not more explicit as to the exact level of the market. Still, these terms must be recorded in the terminology of the stock market, in spite of their frustrating vagueness as they have been made official by use; a foreign student or a translator will need to have a source of reference in order to avoid using just any term that might connote human experience but is not a "received" term. (Resche 1997: 490, 496)

The various linguistic processes that we have examined draw our attention to a common denominator - the omnipresent human dimension — which may have a greater impact in such fields as economics than in other, more exact, sciences. By this, we mean that in many economic situations, the terms used and their meanings are coloured by the viewpoints expressed and a same term will have a positive or negative connotation according to which side the author or the reader is on. We are far, indeed, from the theoretical univocal nature of terms recommended by the rigorous Viennese terminological tradition set forth by Eugen Wüster!

\section{FROM MISUSE TO ABUSE}

It remains for us to determine what can account for the presence of flexible, twosided terms in economic terminology and for their unconscious or conscious use and abuse.

\subsection{The term as a two-sided coin}

The term recession, which we have already mentioned to illustrate the impact of time on meaning and the need to update definitions, will again be used here as an example of psychologically-loaded terms. Although we have established that there is a modern, official definition of "recession," it is interesting to observe that businessmen and politicians tend to avoid the term altogether and to describe recessions as 
cyclical downturns. As The Economist (December 5 1998, "Bubble Babble") points out, however, the logic that pushes them to choose a soft alternative for the negativesounding term no longer applies when it comes to mentioning economic booms which are never referred to as "cyclical expansions." The financial weekly magazine accounts for this terminological abuse as follows:

This is convenient: bad times are the fault of impersonal economic forces; good times the result of far-sighted human decisions.

The same sort of bias is apparent when Wall Streeters comment on fluctuations in stock prices. Characteristically, they are more precise when they are faced with a decline in share prices than when they deal with a rise, which they more readily call a bull market. Obviously, they are more reluctant to call a falling market a "bear market," and they make sure to distinguish different types of losses. They insist that for a market to be officially called a bear market, there has to be a $20 \%$ drop at least. Their appreciation of a declining market is therefore more carefully measured: for a fall of $5 \%$, the proper term is a blip, and a correction corresponds to a fall of $10 \%$.

Again, the latter term correction, in spite of the apparently clear definition, is not always used accordingly. It is considered somewhat differently by financial journalists or forecasters, especially in circumstances when prices fall while they had predicted a rise. They will typically avoid such terms as "decline" and resort to correction instead, to suggest that what is happening is just a technical readjustment.

Falling prices do inspire imagination: they will often be commented upon as being volatile, but oddly enough, only falling prices are "volatile." Once they start rising again, they have stabilised, implying that such rises reflect economic fundamentals. Paradoxically, irrational gains in share prices are described in terms of stability while a return to more sensible levels is seen as instability. This view is not only biased, it is dangerous and confusing as it implies that extravagant rises are normal and sustainable.

To quote a last example, in the context of growth this time, if new figures show that growth is faster than expected and share prices rise, analysts will announce hopes of stronger profits, while falling share prices will be blamed on fears of higher interest rates, and not "fears of heavy losses."

Depending on circumstances or on who is speaking or writing, an economic development will be considered as "good news" or "bad news" and the same terms will carry a positive or a negative emotional weight. When lower oil prices are announced under the heading oil-price gloom, the paper will probably sell well, but the news is likely to be exaggerated. It is true that oil producers will take it as bad news, but consumers may receive it as good news. We have to realise that, very often in the field of economics, for every loser there is a winner. Strikingly, even a rise in interest rates, which is pronounced bad news - it forces firms to cut investment and jobs and affects borrowers - can be regarded as good news for savers who will gain from higher rates. ${ }^{2}$ The Economist (February 20th 1999) stresses the fact that deflation is not necessarily bad, though the word is often negatively connoted:

Indeed, productivity-driven deflation, in which costs and prices are pushed lower by technological advances or by deregulation, is beneficial, because lower prices lift real incomes and hence spending power.... Deflation is dangerous, on the other hand, when it reflects a sharp slump in demand, excess capacity, and a shrinking money 
supply — as in the early 1930s.... Today's deflation comes in both benign and malign guises.

The sector of trade offers a rich source of examples of emotionally-coloured, misleading terms. Invariably, when they write about trade balances, economic analysts will describe a shrinking trade deficit as improving, but a disappearing trade surplus will be said to be deteriorating. Such associations tend to translate the fallacious principle that a surplus is good and a deficit is bad. Let it be noted besides that "an improving deficit" is a misnomer as a deficit can be said to increase or decrease, widen or shrink, but in no way can it "improve" (Lerat 1995: 145). As Samuelson (1998: 683) points out,

In an earlier era, the mercantilists strove for a "trade surplus" (an excess of exports over imports), calling this a "favorable balance of trade." They hoped to avoid an "unfavorable trade balance," by which they meant a trade deficit (an excess of imports over exports).

This point of view may still have an influence today as many nations seek trade surpluses. However, counter examples point to the relative truth of all this: Japan's widening trade surplus reflects the depressed state of its economy while the United States' trade deficit does, in fact, cohabit with a strong, healthy economy.

Another case of blurring is that of the notions of fair and unfair in trade, which echoes the fogginess surrounding the notions of "good" and "bad" in other areas. As The Economist (February 20th 1999, "Treacherous Trade”) remarks, American trade unions often complain that Mexicans' lower wages give them an "unfair advantage" while Mexicans, for their part, say they cannot compete "fairly" against their more productive American counterparts. Actually, it is now an established fact that freer trade is mutually beneficial, so that both sides here have a wrong approach to "fair" and "unfair."

Trade talks also evidence misused, misleading terms. When governments lower barriers to imports, they are said to make concessions to each other as if free trade required a costly sacrifice. The same negative ring can be noted in the term burden as denounced by The Economist when the United States and Europe accuse each other of being reluctant to "bear the burden" of increased imports from Asia. This expression suggests that only exports are good and that buying imports means heroically consenting to a sacrifice. Actually, economic research has shown that even if countries lower trade barriers unilaterally, they are better off. First, cheap imports provide consumers with a wider choice of goods; then they put pressure on domestic producers to lower their prices to face the increased competition, so that in the end, they are more efficient and realise productivity gains. One can thus justifiably wonder whether "blessing" would not be more accurate than "burden."

\subsection{Semantic sophistry}

Semantic sophistry can be defined as "the practice of using clever arguments that sound convincing but are in fact false." Some of the terms in vogue are indeed vague and flexible enough to be used for purposes of confusion. They are the easy way out of an embarrassing situation, the ultimate arguments, similar to trump cards up economists' sleeves. 
To illustrate this point, we shall consider the debate for or against government intervention in economic matters. If an economist wants to argue in favour of government intervention against something he considers as a nuisance, he will denounce the troublesome effects to society as a negative externality. In a December 1998 issue, The Economist decided to push the argument to the extreme in order to underline the perverse potential effect of such a trick. It argued that "there should be child-free zones on all airlines and that children on aeroplanes should be taxed to compensate for their 'negative externality' — i.e. noise." If, on the contrary, an economist wishes to argue against government intervention, he will be able to resort to another of these joker terms, moral hazard. The term refers to the idea that if individuals, banks or countries are confident that they will be rescued in some way in case they should be in trouble, they will be likely to take bigger risks. For example, if banks trust the government to fly to their rescue or if ailing economies count on the IMF for bailing them out, they are likely to consider that failure is not so dreadful a risk. "Moral hazard" is obviously commonly used by the advocates of the free-market economic model.

Two other terms are fuzzy enough to be conveniently twisted. Transparency is one and credibility the other. Whenever economists or politicians are trapped in an uncomfortable debate, unable to account for the causes of a problem, they will call for more "transparency," as fuller disclosure of information might indeed help them to identify the causes that so far have escaped their scrutiny. As for "credibility," it provides a wonderful illustration of terminology revisited. Again The Economist (March 13th 1999, "Five-Card Brag") observes:

if economists think a country should defend its exchange rate, they will tell the government to raise interest rates (even if it means recession) to maintain its credibility. If, on the other hand, they think it should devalue, they argue that raising interest rates will not be seen as credible (because it means recession).

Clearly, in such instances, terms are consciously used to suit the purposes of those who express their views, and become the trees that hide the forest. The fact is that the same terms can be used to mean one thing and its exact opposite, resulting in terminological fudge.

\section{CONCLUSION}

At this point, the reader will have no problem understanding the full scope of the title of this paper, since the terms which have aroused our interest all along are all likely to result in confusion or obfuscation in one way or the other.

We would now like to relate the time factor which we mentioned in our first part to the notion of fads, fashions and trends. We have already stressed the influence of time on the evolution of meanings and the need to constantly be on one's guard to update definitions. One way of accounting for the fluctuations in terminology is precisely to consider the relative validity of the solutions to economic problems brought by successive schools of economic thinking. Not only does research evolve to question, qualify or even contradict former findings, but changing contexts also force one to humility. At present, for example, old benchmarks are being questioned ${ }^{3}$ and we can hear that we have entered a new era, that of "the New Economy." This calls for 
a constant reappraisal of the notions. As a result, the terminology can only reflect the hesitations, contradictions and fluctuating interpretations.

A second link between time and fashions is that, as a social science, economics is not immune to the trends and fashions that influence society at large. Unavoidably, when new ways of thinking shape social behaviour and condition human relationships, they will be mirrored in the terminology of the period. Thus, the last decade has been marked by the dictates of politically correct do's and don'ts, which have been reflected in the wave of euphemisms recorded in the terminology of corporate restructuring and redundancies. It was and is important to be "managerially correct," to cushion the effects of painful policies. One may wonder, however, whether it is "terminologically correct" or also "morally correct" to resort to understatements and roundabout phrases that, for the sake of being "politically correct," fail to respect the fundamental principles of terminology, i.e. to be precise and clear in expressing concepts and notions.

Be it as it may, as an observer, our role does not consist in banning such terms, which would be "incorrect," but in pointing out the existence of a soft, flexible terminology, more characteristic of social sciences, which has to be carefully recorded as a complement to the more traditional, hard core variety. In the same way as neologisms are observed and recorded as language in the making and as a mirror image of the mentalities in a given period (Resche 1998b: 199-200), these loose, potentially misleading terms - precisely because they are misleading - should be tracked to help the users, especially students working on English as a foreign language, or translators, to avoid the pitfalls and to be able to penetrate the darker corners of the terminology of the specialised branches they strive to master.

\section{APPENDIX 1}

\section{List of the terms examined}

1. Corporate management

career centres

delayering

downsizing

empowerment

inplacement

outplacement (/ offices)

plateauing

rationalising

re-engineering

restructuring

rightsizing

slimming

to be between jobs

to be externalised

to be kicked upstairs

to develop one's career elsewhere

to go into repositioning

to put one's career on hold

to take gardening leave

to spend more time with the family 
2. Economic analysis

- boom

- business cycle

- contraction

- creative accounting

- curve / flat curve

- downturn /cyclical downturn

- deflation / D-word

- expansion

- imperfectly-anticipated inflation

- $\quad$ I-word (inflation)

- moral hazard

- $\quad$ negative externality

- $\quad$ P-word (privatisation)

- $\quad$ recession / R-word

- transparency

- $\quad$ zero slope

\section{Investments, price levels}

- bear market

- blip

- bull market

- correction

- eurobond

- eurocurrency

- euromarket

- fears of higher interest rates

- $\quad$ hopes of stronger profits

- gloom

- $\quad$ hedge fund

- instability

- $\quad$ stabilised prices / stability

- technical readjustment

- volatile prices

4. Trade

- concessions

- fair trade

- $\quad$ terms of trade

- $\quad$ trade concessions

- $\quad$ trade deficit / improving trade deficit

- $\quad$ trade surplus / deterioration trade surplus

- unfair trade

- voluntary export restraints

\section{NOTES}

1. Our reference to time should not be taken to mean looking for etymologies. The evolution which we consider as worth tracking is that over a decade or two.

2. According to The Economist (February 20th 1999), deflation "like many economic concepts, is a widely misunderstood and often misused term. Its proper definition is a persistent fall in the general price level of goods and services. It is not to be confused with a decline in prices in our economic sector, or with a fall in the inflation rate (which is known as disinflation)."

3. The interest rate is simply the price that balances the demand and supply of capital.

4. A striking example concerns the trade-off between unemployment and inflation observed by the economist A.W. Phillips, who gave his name to the well-known Phillips curve. The simple relationship depicted in the Phillips curve began to look inappropriate in the late 1960s, as many western 
countries experienced a simultaneous rise in unemployment and inflation, a phenomenon that came to be described as stagflation. The Phillips hypothesis was changed by the American monetarist Milton Friedman into the assumption that the government cannot push the actual rate of inflation below the natural rate of unemployment without triggering more inflation. NAIRU - the non-accelerating inflation rate of unemployment was first estimated to be $6 \%$. This benchmark is no longer valid, though, as the unemployment rate in the United States has been well below the $6 \%$ threshold for quite a while and yet, no inflation has been generated.

\section{REFERENCES}

Bally, C. (1935): Le langage et la vie, $2^{e}$ éd., Zurich, Max Niehans.

Barro, R. J. and V. Grilli (1994): European Macroeconomics, London, The Macmillan Press Ltd. Bouveret, M. (1998): “Approche de la dénomination en langue spécialisée," Meta, 43-3, Presses de l'Université de Montréal.

Brett, M. (1992): How to Read the Financial Pages, London, Century Business.

Deconinck-Brossard, F. and B. Offerle (1996): Reading Economics, Paris, Ellipses/Édition Marketing S.A.

Dornbusch, Rudiger and Stanley Fischer (1988): Macroeconomics, McGraw-Hill International Editions.

Dubuc, Robert (1980): Manuel pratique de terminologie, Montréal, Paris, Linguatech et Conseil International de la Langue Française.

GUILBERT, Louis (1965): La formation du vocabulaire de l'aviation, Paris, Larousse.

Lerat, Pierre (1995): Les langues spécialisées, Paris, Presses Universitaires de France.

Matthews, Peter Hugoe (1997): Concise Dictionary of Linguistics, Oxford, Oxford University Press.

MøLleR, Bernt (1998): “A la recherche d'une terminochronie," Meta, 43-3, Presses de l'Université de Montréal.

Resche, Catherine (1997): "Prolégomènes à la phraséologie comparée en langue de spécialité: exemple de l'anglais et du français de la finance," p. 487-503, Asp 15-18 (La revue du Geras), Bordeaux, Université de Bordeaux 2.

- (1998a): "Discours métaphorique et monnaies: les particularités de l'euro," p. 67-88, Asp 1922 (La revue du Geras), Bordeaux, Université de Bordeaux 2.

- (1998b): "De l'Europe à l'euro ou l'industrieuse activité de la langue: recensement et analyse des néologismes en anglais et en français de 1991 à 1998," p. 185-208, Asp 19-22 (La revue du Geras), Brodeaux, Université de Bordeaux 2.

SAGER, Juan C. (1981): "Criteria for Measuring the Functional Efficacy of Terms," p. 194-217, Infoterm Series 6, Munich, K. G. Saur Verlag K. G.

Samuelson, Paul Anthony and William D. Nordhaus (1998): Economics, McGraw-Hill.

Saussure, Ferdinand de (1969): Cours de linguistique générale, Paris, Payot. 